\title{
Biological effects of argentine asbestos: mineralogical and morphological characterisation
}

\author{
Leticia Lescano $\cdot$ Norberto A. Gandini • \\ Silvina A. Marfil · Pedro J. Maiza
}

Received: 19 November 2013/Accepted: 18 August 2014/Published online: 27 August 2014

(C) Springer-Verlag Berlin Heidelberg 2014

\begin{abstract}
Asbestiform minerals, namely serpentine (chrysotile) and amphiboles (tremolite-actinolite) as well as others of fibrous habit (sepiolite) from Argentine deposits were characterised to assess their biological hazard. Materials currently used as asbestos substitutes were also assessed (glass fibre and ceramic fibre). Studies with laboratory animals were conducted. Sixty mice ( 30 females and 30 males), 8 weeks old, were used following the good practices in the care and handling of laboratory animals. They were split into six groups of ten mice each (5 females and 5 males), designated as control, tremolite, glass fibre, chrysotile, sepiolite and ceramic fibre, and were exposed by inhalation to these previously ground materials. The animals were examined throughout the experiments to see how they responded to the inhaled substances to establish the effects of inhalation at the time of exposure and once they had been killed. The respiratory tract (trachea, bronchi and lungs) of the animals exposed to the different materials was examined in tissue sections. Differences in the amount of connective tissue in the lungs and the presence of alveolar macrophages were observed in the animals exposed to tremolite, chrysotile and sepiolite, as compared to the control group. It was concluded that, of all the materials
\end{abstract}

L. Lescano · S. A. Marfil · P. J. Maiza

Geology Department, Universidad Nacional del Sur,

San Juan 670, Bahía Blanca, Argentina

L. Lescano · S. A. Marfil ( $\square)$

Researcher at Comisión de Investigaciones Científicas de la

Prov. de Buenos Aires, Buenos Aires, Argentina

e-mail: smarfil@uns.edu.ar

\section{N. A. Gandini}

Laboratorio de AnatamoHistología, Biology, Biochemistry and Pharmacy Department, Universidad Nacional del Sur,

CONICET, Bahía Blanca, Argentina used, amphiboles caused greater damage and an incipient development of carcinogenesis. The other ones, especially chrysotile, produced connective tissue thickening.

Keywords Asbestos - Carcinogenesis - Asbestosis · Amphibole $\cdot$ Chrysotile

\section{Introduction}

Asbestos comprises different minerals with similar morphological characteristics that are very long and thin, acicular, generally with hackly fracture; they occur in bundles with a large number of fibres, have high tensile strength and electrical resistance, and are non-combustible. Some of them exhibit other particular properties that determine their specific use, so that they have been widely employed in many industries.

Asbestos minerals fall into two groups: serpentine (chrysotile) and amphiboles. They are both silicate minerals but with different mineralogical, morphological, physical and chemical characteristics (Skinner et al. 1988).

Tremolite and actinolite belong to the calcic amphibole series in which the iron and magnesium content can vary (Leake et al. 1997) and, along with other amphiboles, they may exhibit asbestiform morphology. Their occurrence as accessory minerals in the ores of currently exploited deposits poses a potential health risk (Goodwin 1974).

Chrysotile is a mineral of the serpentine group that develops from the alteration of other minerals, mainly olivines, pyroxenes and amphiboles. Its structure consists of layers of concentric cylinders, which is the typical asbestiform mineral habit (Wicks and Whittaker 1975). Within the asbestos group, chrysotile has been the most commonly used worldwide. 
Sepiolite is a naturally occurring phyllosilicate, of fibrous habit, whose structure consists of channels running parallel to the fibres, called zeolitic channels, which are responsible for most of its properties, among them its absorbing capacity (Jones and Galán 1988). The morphology of sepiolite has sparked scientific debate due to its toxicity and it may be included in the asbestos group in future regulatory legislation (Rodríguez 2004).

In Argentina, the production, importation, commercialisation and use of fibres of amphibole and chrysotile asbestos or the products containing them have been prohibited as per Resolutions of the Health Ministry No. $845 / 00$ and $823 / 01$ from 10 October 2000 to 1 January 2003, respectively (Rodríguez 2004). Although these resolutions are still in force, currently adopted measures include product withdrawal from the market, their removal and replacement by other materials.

Asbestos is dangerous due to its morphology rather than to its chemical composition. According to Valeyre and Letourneaux (1999), the most important properties that make asbestos hazardous are fibre durability, stability and biopersistence.

A large number of epidemiological studies have associated asbestos exposure to certain diseases. It has been shown that exposure to these materials causes lung diseases, some of which are malignant (Kang et al. 2013; Sánchez et al. 2009). The main health effects of asbestos are: asbestosis (Camelo et al. 2014), lung cancer (Kang et al. 2013), malignant mesothelioma (Robinson 2012) and pleural plaques (Roggli and Vollmer 2008). Lung diseases were first reported in 1899 (Murray 1907), although they were not associated with asbestos up to 1927, when the term pulmonary asbestosis was introduced and differences from other pneumoconiosis were reported (Marín Martínez and Clavera 2005). Asbestosis, a form of progressive diffuse interstitial pulmonary fibrosis, is the most common disease. The inhaled fibres cause inflammatory lesions in lung tissues, which leads to scarring and shortness of breath (Camelo et al. 2014). The fibres are breathed in, with the smallest ones $(<3 \mu \mathrm{m})$ reaching the lower airways. The long, curly chrysotile fibres are trapped in the less peripheral bronchioles, whereas the opposite occurs with the short, straight, stiff amphibole fibres (Duncan et al. 2014; Bernstein et al. 2013). During alveolar clearance, the particles may undergo physical and chemical changes such as ferroprotein coating (asbestos bodies) (Dodson et al. 2005). First, alveolitis develops due to the activated alveolar macrophages that release chemotaxins, fibroblast growth factors and protease (Camelo et al. 2014; Nishimura et al. 2013). Chemotaxins attract neutrophils and, together with macrophages, may release oxidants capable of oxidising epithelial cells, and fibroblast growth factors gain access to the interstitium. Mineral particles would act as catalytic substrate for the formation of oxidising radicals: reactive oxygen species (ROS) and reactive nitrogen species (RNS) associated with cell damage, DNA damage, mutagenesis and apoptosis (Camelo et al. 2014). Asbestos pathogenicity probably derives from the long-term interplay between persistent free-radical production and the expression of cytokines, growth factors and other inflammatory cell products (Camelo et al. 2014; Nishimura et al. 2013).

In Argentina there are few and isolated records of pathological studies on asbestos. Matos et al. (1997) made the Atlas of Cancer Mortality in Argentina between 1989 and 1992, where they reported cases of lung cancer and the follow-up of patients in Buenos Aires, with occupational exposure measurements in 600 individuals (200 cases and 400 controls); asbestos-related exposure was found in $20 \%$ of the cases. Casado (1999) surveyed lung cancer patients about their jobs to determine the length of exposure time to asbestos at their workplaces. They had been exposed to asbestos for 15 years in a range of 4-23 years and the latency period until neoplasia had been diagnosed was very long (about 20 years). Ninety-eight per cent of the patients with malignant mesotheliomas had been occupationally exposed to asbestos.

The mineralogical study is essential for assessing asbestos potential impact on human health, especially for fibre morphology and resistance to natural degradations processes.

In Argentina there are no records of studies on the biological hazard of naturally occurring asbestos minerals. Asbestos minerals were mobilised and/or mined in specific deposits for decades until late 1990, when their commercialisation and exploitation were prohibited; however, they are still mobilised as minerals associated with talc and vermiculite ores. In addition, there are no regulations on the mobilisation of materials containing these minerals or on the precautions to be taken for their disposal.

The aim of the work described in this paper was to assess the biological hazard of asbestiform minerals of the serpentine (chrysotile), amphibole (tremolite-actinolite) group, as well as that of other fibrous habit minerals such as sepiolite from Argentine deposits and materials currently used as substitutes (glass and ceramic fibres).

\section{Materials and methods}

\section{Mineralogical characterisation}

Asbestiform minerals, namely serpentine (chrysotile) and amphiboles (tremolite-actinolite) as well as others of fibrous habit (sepiolite) from Argentine deposits were characterised to assess their biological hazard. Samples 
were analysed by X-ray diffraction (XRD) with a Rigaku D-Max III-C X-ray diffractometer with $\mathrm{Cu} \mathrm{K} \alpha$ radiation and a graphite monochromator operated at $35 \mathrm{kV}$ and $15 \mathrm{~mA}$. The minerals were identified with an Olympus SZPt trinocular stereomicroscope, an Olympus B2-UMA trinocular petrographic microscope and a JEOL JSM 35 CP scanning electron microscope (SEM-EDS). Morphological and fibre size studies were carried out, taking into account their length to width ratio.

\section{Experimental study}

In vivo studies were conducted in accordance with institutional procedures, Canadian Federal Guidelines and the NIH Guide for the Care and Use of Laboratory Animals.

Sixty CF51 mice (30 females and 30 males), 8 weeks old, (acceptable age range between 6 and 10 weeks) were used; they were manually handled to avoid stress. Good practices for handling laboratory animals were followed (Guide for the Care and Use of Laboratory Animals 1996). The guidelines proposed by Organisation for Economic Co-operation and Development (OECD) and the The Environment, Health and Safety (EHS) division were followed. Each stage of analysis was performed in accordance with the OECD Series on Testing and Assessment No. 39: Guidance Document on Acute Inhalation Toxicity Testing, where all the conditions for the simulations of airflows and inhalation of toxic material by animals are standardised (OECD 2009).

The animals were split into six groups of ten each (5 females and 5 males), namely, A: control group (only a flow of fresh air was supplied to the chambers); B: tremolite group; C: glass fibre group; D: chrysotile group; E: sepiolite group; and F: ceramic fibre group. For the experiment, the mice were taken to the inhalation chambers (Fig. 1), which consisted of two plastic containers of similar size to that of the dwelling cages with an opening for the supply of air and ground material. A constant airflow was supplied by a 24 psi compressor, equivalent to $160 \mathrm{~L}$ of air and $50 \mathrm{mg}$ of sample/L. The minerals and substitutes were previously ground in an agate mortar to less than $3 \mu \mathrm{m}$.

At the end of the treatment period (14 days), the animals were anaesthetized, killed and the tracheopulmonary block was removed. Tissues were fixed in $10 \%$ formaldehyde in buffer PBS $1 \times$ for $24 \mathrm{~h}$, dehydrated in alcohols of increasing grade $\left(70^{\circ}, 95^{\circ}\right.$ and $\left.100^{\circ}\right)$ up to xylol. They were then embedded in paraffin to form the tissue block. Fivemicron sections of the tissue were cut and stained with haematoxylin (according to Harris) and eosin, and with Masson's trichrome to examine the connective tissue. The anatomical and pathological characteristics were recorded daily (Pérez et al. 2006).

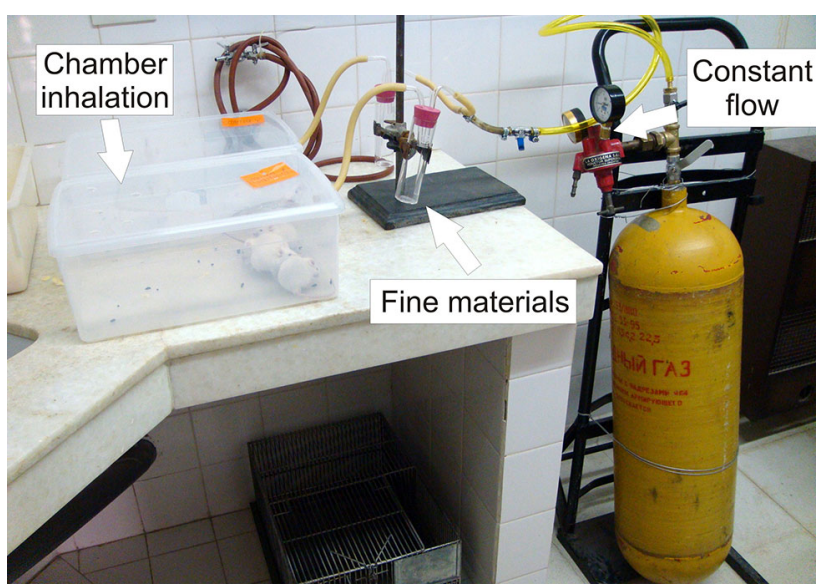

Fig. 1 Animal inhalation chambers

Tissue sections were examined using a histochemical score to assess the intensity of Masson's trichrome staining (TRS). The TRS was calculated by multiplying the trichrome staining intensity score (scores: $0=$ no staining; $1=$ weak staining; $2=$ moderate staining, and $3=$ strong staining) by the percentage of stained fibres observed (scores $0=$ less than $10 \% ; 1=11-50 \%$ of fibres; $2=51-80 \%$ of fibres, and $3>81 \%$ of fibres). The TRS mean value for each tissue section was determined by examining 10 random histological fields with $400 \times$ total magnification of the microscopic field. Tissue sections with TRS $>0$ were considered to have increased connective tissue. The one-way analysis of variance (ANOVA) was used to compare the groups under study. The Chi square test was employed for data analysis using the software GraphPad Prism 5.01 for Windows. Significant differences with $p<0.05$ were identified.

Tissue sections were imaged with an Olympus BX51 microscope with Olympus C7070 digital camera. Ten random fields were examined for changes in the lung tissue morphology.

\section{Results and discussion}

Mineralogical characterisation

The amphiboles analysed were collected from the Salamanca mine, province of Mendoza, Argentina, which was mined for talc (Fig. 2Aa) for decades. No environmental studies were ever conducted to determine whether amphibole asbestos were present in the talc ore.

Thin sections of the samples were examined. They are composed of over $95 \%$ of an asbestiform mineral that is colourless to light green, slightly pleochroic with oblique extinction $\left(14^{\circ}\right)$ and does not show signs of alteration since 

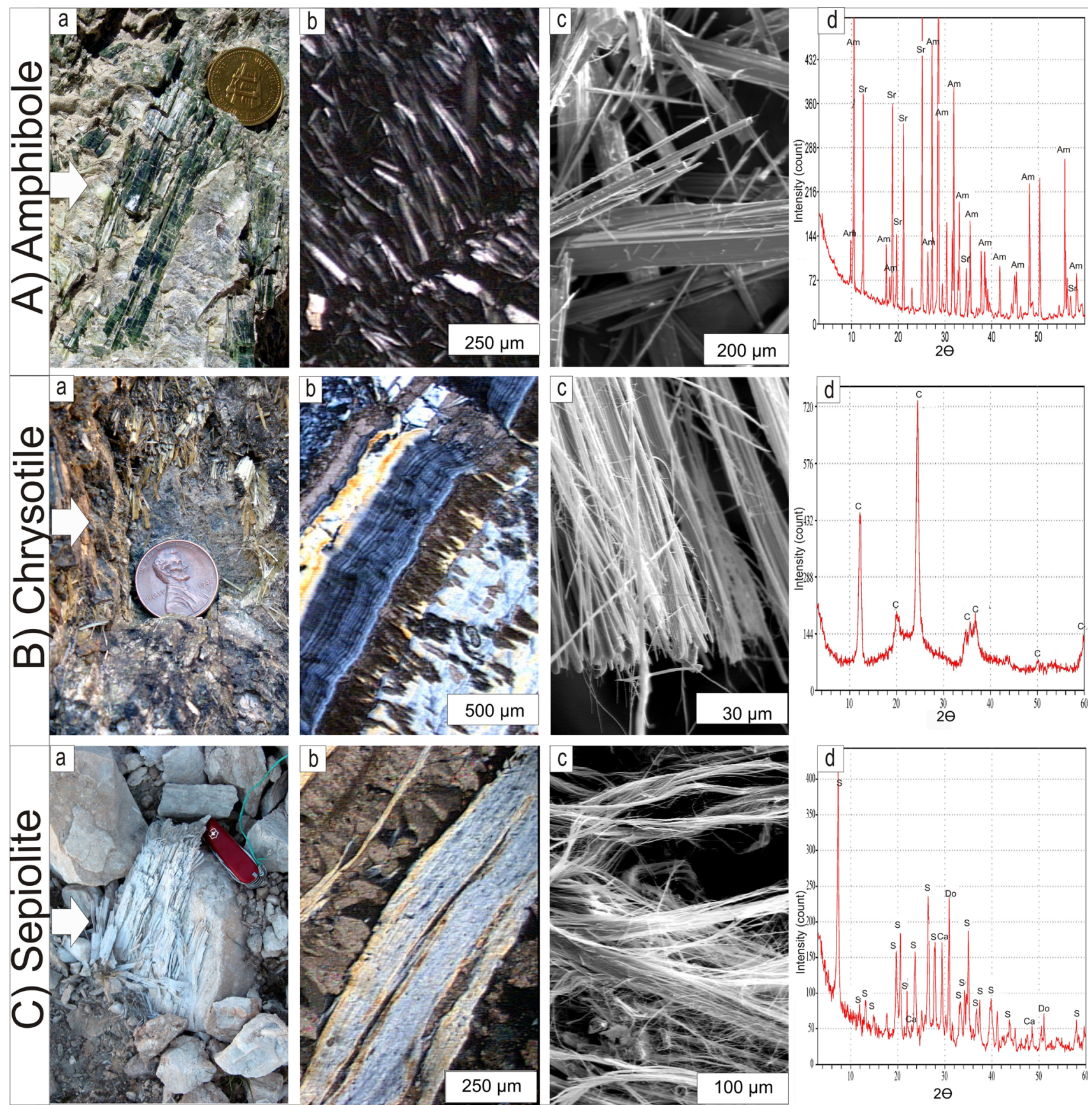

Fig. 2 (A) a Amphiboles of prismatic habit within the steatised rock. b Amphibole fibres in thin sections under crossed nicols. c SEM of amphiboles. d XRD of amphiboles from the Salamanca mine ( $\mathrm{Am}$ amphiboles, $S r$ serpentine). (B) a Chrysotile fibres in the host rock.

it has developed mainly in the talc mass. Due to its optical properties, it was identified as actinolite (Fig. 2Ab). A scarce amount of relict antigorite showing incipient alteration to talc was observed in the intercrystalline spaces. The SEM analysis was performed to identify the morphology of fibres. Figure 2Ac shows rectilinear crystals of stiff and acicular habit, typical of amphibole asbestos. b Irregular banding of fibres in a thin section. $\mathbf{c}$ SEM of fibres. $\mathbf{d}$ XRD of chrysotile (C). (C) a Fibrous sepiolite in the carbonatic rock. b Fibrous sepiolite in carbonatic mass viewed with an optical microscope. c SEM of fibres. $\mathbf{d}$ XRD of sepiolite ( $s$ sepiolite, Do dolomite, $\mathrm{Ca}$ calcite)

X-ray diffraction revealed reflections mostly of the amphibole mineral group, tremolite-actinolite series, with their main peaks at $3,11,8.3$ and $2.7 \AA$, comparable to cards No. 41-1366 and 13-437 (ICDD 1993) for actinolite and tremolite, respectively (Fig. 2Ad). Subordinate amounts of serpentine group minerals, assigned to antigorite, were identified. 
The sample of chrysotile was from the La Bélgica mine, province of Córdoba, Argentina, which is one of the most exploited chrysotile asbestos deposits in Argentina. It was mined since 1947 and its open pit exploitation lasted up to the late 1970s. Chrysotile has a fibrous acicular habit with crystals over $2 \mathrm{~cm}$ long that grow perpendicular to the crack walls (asbestos cross-fibre) (Fig. 2Ba). There is a noticeable progressive degradation of aggregates, which leads to the formation of filiform and acicular particles due to their small size and low specific weight. Thin sections revealed the presence of subparallel veins with irregular, sometimes asymmetric, banding where chrysotile crystallised transversely (Fig. 2Bb). Cross-cutting veins are frequently observed; they belong to a later event with similar textural and morphological characteristics, without displacement, i.e. the crack where the mineral developed did not undergo shearing. Crystals in the vein exhibit parallel extinction. SEM analyses showed that this mineral has a fibrous, asbestiform, extremely flexible morphology and it is intensely split into smaller fibres (Fig. 2Bc). X-ray diffraction confirmed that this mineral is chrysotile (Fig. 2Bd).

The sepiolite sample was from the La Adela mine, province of Río Negro, Argentina, which was mined for carbonatic materials in past decades. Macroscopically, sepiolite occurs in flexible, fibrous aggregates; it is white, very light, relatively soft to touch and of low hardness (2-2.5). The fibres are arranged in bundles and are oriented parallel to cracks within the diaclases of dolomitic rocks, commonly associated with calcite and other minerals (Fig. 2Ca). They show noticeable crystalline development since in some areas the fibres are longer than $10 \mathrm{~cm}$. In thin sections, sepiolite is from colourless to grey, it has low relief, $n<$ balsam and weak birefringence. Extinction is approximately parallel, with positive elongation (length slow). Sepiolite occurs in contact with the dolomitic host rock (Fig. 2Cb). The SEM analysis showed no individual fibres but an interlocking texture. The fibres are very thin and long, and fibre ends cannot be easily identified (Fig. 2Cc). The sepiolite structure and the presence of associated calcite and dolomite were identified by XRD (Fig. 2Cd).

\section{Experimental study}

The animals were examined throughout the experiments to see how they responded to the inhaled substances to establish the effects of inhalation at the time of exposure and once they had been killed.

From the beginning, mice showed nasal disorders when they breathed the air containing amphiboles, and eventually the rest of their body was also affected. A dense whitish cloud, almost imperceptible to the human eye, formed and remained inside the chamber even after the end of the experiment. This cloud was monitored by means of a slide that was coated with an adhesive substance to collect the suspended material in the chamber. The autopsy showed that female mice were less affected than male mice. In general, no external morphological alterations in the abdomen or thorax were detected. However, all the male mice showed different degrees of alteration; the lungs of some of them were darker than the normal pink colour. Reddish petechiae with well-defined and uniform borders were found in the region of the hilum. Subcutaneous fat decreased. The results are summarised in Table 1.

When chrysotile was used, it showed a resistance to float in the air due to fibre bundling and interlocking. From macroscopic observations, it can be said that in general female mice showed no visible alterations; their organs were in situ and their lungs, pink and crackling. Only a small number of tiny dark red petechiae were found on one female mice's lung and another specimen showed pleural effusion from the hilar region to the upper lobe of the left lung. Male mice in general only presented internal alterations, no skin disorders were observed. Three of them developed some small petechiae in the lung region and another one showed larger and thicker petechiae (Table 1).

A relatively dense and whitish cloud formed when sepiolite was used in the inhalation chambers. The macroscopic evaluation revealed that all the animals (females and males) had slight internal alterations such as petechiae on both lungs which, however, were fewer in females. No external alterations or different morphologies were observed. The experiments with glass and ceramic fibres developed normally. These materials have low specific weight and the cloud formed during each exposure was extremely upsetting for the animals. After the experiment, no macroscopic internal or external alterations were found in any of the animals (Table 1).

The respiratory tract (trachea, bronchi and lungs) of the animals exposed to the different materials was examined in tissue sections. Differences in the amount of connective tissue in the lungs and the presence of alveolar macrophages were observed in the animals exposed to tremolite, chrysotile and sepiolite, as compared to the control group. Representative histological fields of the groups under study are shown in Fig. 3. Figure 3a depicts a lung section of a control group animal. One of the striking characteristics of the lungs of animals exposed to tremolite and chrysotile was the loss of the typical morphology of lung tissue, with an increase in nuclear polymorphism being noticed (Fig. 3b, c) (white arrows indicate alveolar wall thickening due to the increase in connective tissue). Figure $3 d$ shows a tissue section of a lung of an animal exposed to sepiolite; $3 \mathrm{e}$, to ceramic fibre and $3 \mathrm{f}$, to glass fibre. 
Table 1 Summary of clinicopathologic results

\begin{tabular}{|c|c|c|c|c|c|c|c|}
\hline \multirow[t]{2}{*}{ Mineral } & \multirow[t]{2}{*}{ Animal } & \multicolumn{2}{|c|}{ Weight (g) } & \multirow[t]{2}{*}{ External alteration } & \multirow[t]{2}{*}{ Internal alteration } & \multirow[t]{2}{*}{ Lung weight } & \multirow[t]{2}{*}{ Petechiae } \\
\hline & & Initial & Final & & & & \\
\hline \multirow[t]{10}{*}{ Control } & QF 1 & 32.2 & 33.9 & No & No & 0.4 & 0 \\
\hline & QF 2 & 31.5 & 32.6 & No & No & 0.5 & 0 \\
\hline & QF 3 & 29 & 32.8 & No & No & 0.4 & 0 \\
\hline & QF 4 & 34.3 & 37.9 & No & No & 0.5 & 0 \\
\hline & QF 5 & 33.6 & 36.4 & No & No & 0.4 & 0 \\
\hline & QM 1 & 43 & 46.4 & No & No & 0.5 & 0 \\
\hline & QM 2 & 36 & 41.2 & No & No & 0.4 & 0 \\
\hline & QM 3 & 40.1 & 43.3 & No & No & 0.4 & 0 \\
\hline & QM 4 & 37 & 39.9 & No & No & 0.6 & 0 \\
\hline & QM 5 & 35 & 39.6 & No & No & 0.5 & 0 \\
\hline \multirow[t]{10}{*}{ Amphiboles } & AF 1 & 24.8 & 30.5 & No & No & 0.3 & 0 \\
\hline & AF 2 & 30.6 & 32.1 & No & No & 0.5 & 0 \\
\hline & AF 3 & 31 & 33.7 & No & Yes & 0.5 & 0 \\
\hline & $\mathrm{AF} 4$ & 26.6 & 28 & No & No & 0.5 & 0 \\
\hline & AF 5 & 28.2 & 30.3 & No & No & 0.2 & 0 \\
\hline & AM 1 & 36 & 38.6 & Yes & Yes & 0.4 & 3 \\
\hline & AM 2 & 37.4 & 41.1 & No & Yes & 0.5 & 5 \\
\hline & AM 3 & 35.3 & 35.5 & Yes & Yes & 0.4 & 5 \\
\hline & $\mathrm{AM} 4$ & 35.6 & 37.4 & No & Yes & 0.4 & 6 \\
\hline & AM 5 & 36.1 & 37.9 & Yes & No & 0.4 & 0 \\
\hline \multirow[t]{10}{*}{ Glass fibre } & FVF 1 & 29.5 & 31.4 & No & No & 0.3 & 0 \\
\hline & FVF 2 & 28.5 & 30.4 & No & No & 0.3 & 0 \\
\hline & FVF 3 & 28.4 & 30 & No & No & 0.2 & 0 \\
\hline & FVF 4 & 26.3 & 27.8 & No & No & 0.3 & 0 \\
\hline & FVF 5 & 30 & 31.8 & No & No & 0.4 & 0 \\
\hline & FVM 1 & 35.1 & 36.1 & No & No & 0.3 & 0 \\
\hline & FVM 2 & 36.1 & 37.1 & No & No & 0.4 & 0 \\
\hline & FVM 3 & 34.6 & 36.5 & No & No & 0.4 & 0 \\
\hline & FVM 4 & 33.6 & 36.7 & No & No & 0.4 & 0 \\
\hline & FVM 5 & 33.8 & 36.9 & No & No & 0.3 & 0 \\
\hline \multirow[t]{10}{*}{ Chrysotile } & CF 1 & 30.5 & 34.1 & No & No & 0.2 & 0 \\
\hline & CF 2 & 27.5 & 28.9 & No & No & 0.3 & 0 \\
\hline & CF 3 & 28.7 & 31 & No & No & 0.3 & 0 \\
\hline & CF 4 & 27.3 & 29.8 & No & Yes & 0.2 & 3 \\
\hline & CF 5 & 29.1 & 30.1 & No & Yes & 0.3 & 2 \\
\hline & CM 1 & 36.2 & 37.8 & No & Yes & 0.3 & 4 \\
\hline & CM 2 & 37.5 & 38.8 & No & Yes & 0.3 & 4 \\
\hline & CM 3 & 34.8 & 36.6 & No & No & 0.4 & 0 \\
\hline & CM 4 & 34.6 & 36.8 & No & Yes & 0.5 & 3 \\
\hline & CM 5 & 32.1 & 33.3 & No & Yes & 0.3 & 3 \\
\hline
\end{tabular}


Table 1 continued

\begin{tabular}{|c|c|c|c|c|c|c|c|}
\hline \multirow[t]{2}{*}{ Mineral } & \multirow[t]{2}{*}{ Animal } & \multicolumn{2}{|c|}{ Weight (g) } & \multirow[t]{2}{*}{ External alteration } & \multirow[t]{2}{*}{ Internal alteration } & \multirow[t]{2}{*}{ Lung weight } & \multirow[t]{2}{*}{ Petechiae } \\
\hline & & Initial & Final & & & & \\
\hline \multirow[t]{10}{*}{ Sepiolite } & SF 1 & 27.5 & 29.3 & No & Yes & 0.3 & 2 \\
\hline & SF 2 & 28.3 & 30.9 & No & Yes & 0.2 & 3 \\
\hline & SF 3 & 28.9 & 31.1 & No & Yes & 0.2 & 2 \\
\hline & SF 4 & 28.3 & 31.2 & No & Yes & 0.3 & 3 \\
\hline & SF 5 & 27.5 & 29.3 & No & Yes & 0.3 & 2 \\
\hline & SM 1 & 30.2 & 33.2 & No & Yes & 0.4 & 3 \\
\hline & SM 2 & 34.8 & 37.4 & No & Yes & 0.4 & 2 \\
\hline & SM 3 & 36.1 & 38.4 & No & Yes & 0.3 & 3 \\
\hline & SM 4 & 33.6 & 35.8 & No & Yes & 0.4 & 3 \\
\hline & SM 5 & 34.1 & 35.6 & No & Yes & 0.4 & 1 \\
\hline \multirow[t]{10}{*}{ Ceramic fibre } & CFF 1 & 28.5 & 31.2 & No & No & 0.3 & 0 \\
\hline & CFF 2 & 30.4 & 32.3 & No & Yes & 0.3 & 0 \\
\hline & CFF 3 & 28.7 & 30.4 & No & No & 0.4 & 0 \\
\hline & CFF 4 & 26.3 & 27.6 & No & No & 0.2 & 0 \\
\hline & CFF 5 & 27.5 & 30.3 & No & No & 0.3 & 0 \\
\hline & CFM 1 & 34.9 & 37.2 & Yes & No & 0.4 & 0 \\
\hline & CFM 2 & 37.5 & 39.1 & No & No & 0.4 & 0 \\
\hline & CFM 3 & 35.3 & 37.8 & No & No & 0.3 & 0 \\
\hline & CFM 4 & 35.9 & 37.5 & No & No & 0.4 & 0 \\
\hline & CFM 5 & 37.1 & 39.8 & No & Yes & 0.3 & 0 \\
\hline
\end{tabular}

In all the groups $\mathrm{M}$ : male, $\mathrm{F}$ : female, and the figure indicates the number of animals studied

$Q$ control group, $A$ amphibole, $G F$ glass fibre, $C$ chrysotile, $S$ sepiolite, $C F$ ceramic fibre

The microscopic examination of Masson's trichrome staining revealed that the group exposed to tremolite had TRS 4.7 (mean 4.7, range 3-6) with greater presence of connective tissue as compared to the normal tissue $(p<0.0001)$. The lungs of animals exposed to chrysotile also had a larger amount of connective tissue with TRS 2 (mean 2, range 0-4) as compared to the control group $(p=0.0075)$. The other groups showed no differences in the amount of connective tissue with respect to the control group (glass fibre: TRS 0.2, mean 0.5 , range $0-1$, $p=0.3434$; sepiolite: TRS 0.8 , mean 0.8 , range $0-2$, $p=0.1382$; and ceramic fibre: TRS 0.8 , mean 0.8 , range $0-2, p=0.2729$ ) (Fig. 4).

Laboratory animal studies were conducted to assess the harmful potential of the materials tested. It is not easy to extrapolate animal test results to humans because the differing sizes and shapes of asbestos make risk and hazard assessments difficult. Some forms of asbestos such as amphiboles, crocidolite, amosite or tremolite are pathogenic in short-term exposure (less than a year) and other varieties such as chrysotile are pathogenic after prolonged exposure (Van Oss et al. 1999). In this experiment, of all the materials used amphiboles caused greater damage and incipient development of carcinogenesis. The others, mainly chrysotile, caused less connective tissue thickening. These results are in agreement with those reported by Rowlands et al. (1982), Albin et al. (1994), Bernstein et al. (2005), among others, who showed in experimental animals that chrysotile fibres cause low degrees of aggressiveness as compared to amphiboles. Ross et al. (1993) maybe were the first researchers to arrive at the conclusion that not all forms of asbestos are equally carcinogen or harmful to health.

In addition, there are toxicological controversies about the morphology of amphiboles. Davis et al. (1991) carried out a study where they showed that the different morphology of tremolite (fibrous asbestiform and non-asbestiform) produces carcinogenesis with different degrees of aggressiveness. The underlying reason is that cleavage fragments, when inhaled, would be less harmful than fibres (Davis et al. 1991). The amphiboles used in the present work have asbestiform morphology, but no prior selection was made, i.e. many of the crystals inhaled may have had non-asbestiform morphology. The results show positive incidence without a prior selection of crystal habits, in agreement with the report by Davis et al. (1991).

Santarén and Álvarez (1994) reported epidemiological results from animal experiments that involved inhalation of 


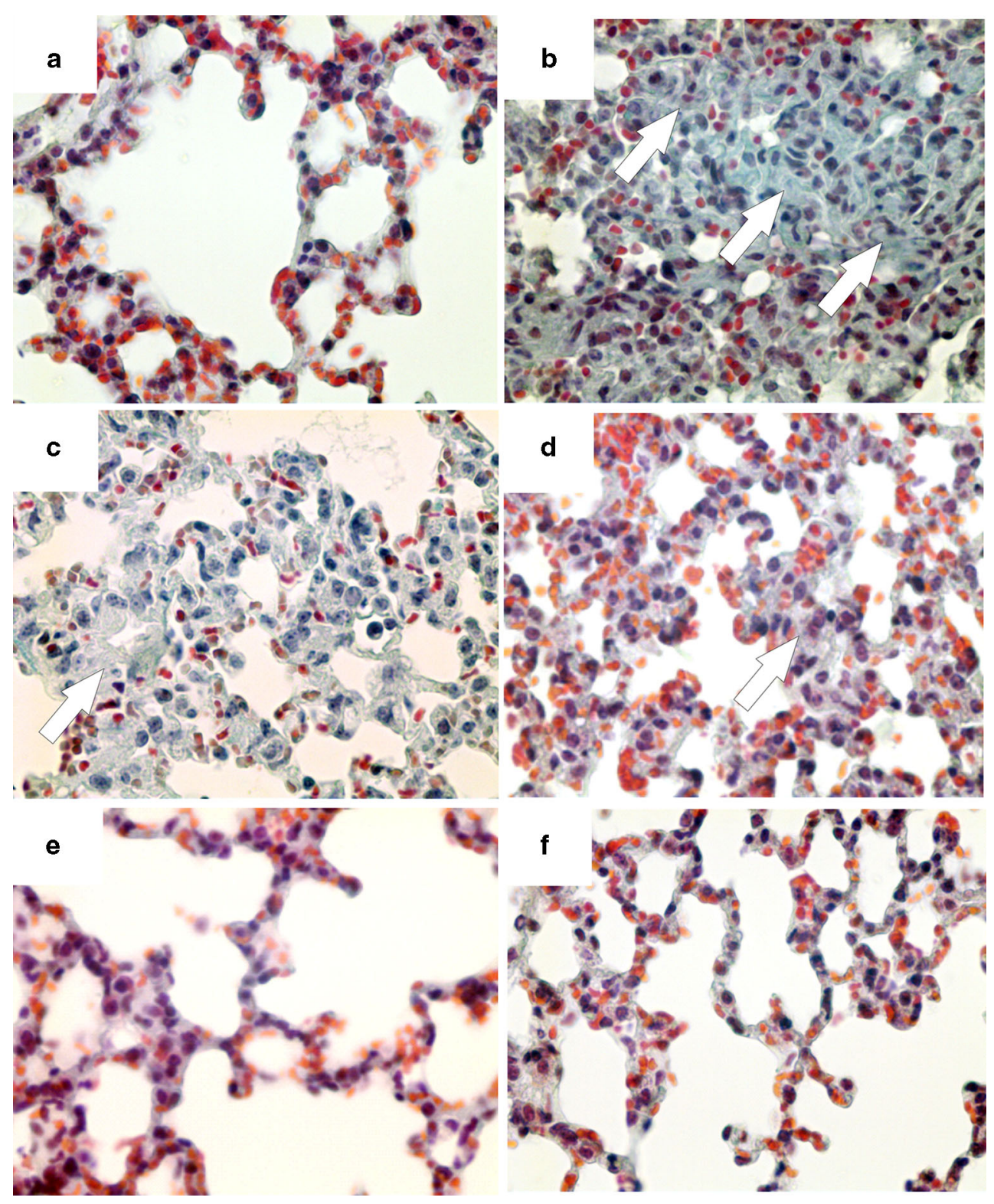

Fig. 3 Sections of the lungs studied (photomicrographs, $\times 400$ magnifications). a Tissue section of a control animal's lung. b Image of a lung of an animal exposed to tremolite. White arrows indicate alveolar wall thickening due to the increase in connective tissue. c Tissue section of a lung of an animal exposed to chrysotile. d Tissue section of a lung of an animal exposed to sepiolite. e Lung of an animal exposed to ceramic fibre. $\mathbf{f}$ Representative section of a lung of an animal exposed to glass fibre
Fig. 4 Microscopic analysis of Masson's trichrome staining

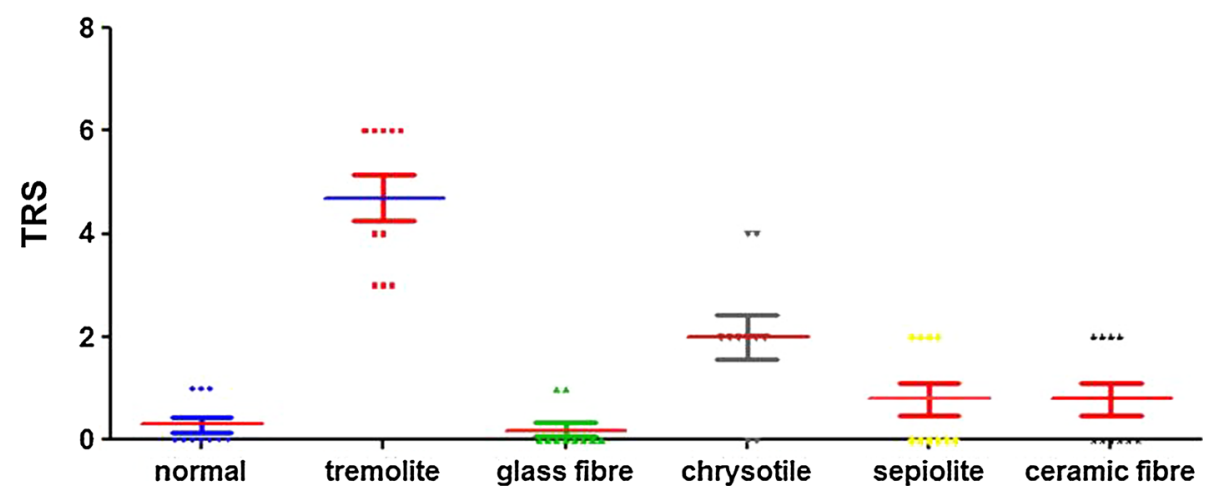


Table 2 Observations during the experiment and macroscopic examination

\begin{tabular}{|c|c|c|c|c|c|c|c|c|c|c|c|}
\hline \multirow[t]{2}{*}{ Animal } & \multicolumn{2}{|c|}{ Weight (g) } & \multirow[t]{2}{*}{ Difference } & \multirow[t]{2}{*}{$p$} & \multirow[t]{2}{*}{ External alteration } & \multirow[t]{2}{*}{$p$} & \multirow[t]{2}{*}{ Internal alteration } & \multirow[t]{2}{*}{$p$} & \multirow[t]{2}{*}{ Lung weight } & \multirow[t]{2}{*}{$p$} & \multirow[t]{2}{*}{ Petechiae } \\
\hline & Initial & Final & & & & & & & & & \\
\hline QF1 & 32.2 & 33.9 & 1.7 & & No & & No & & 0.4 & & 0 \\
\hline QF 2 & 31.5 & 32.6 & 1.1 & & No & & No & & 0.5 & & 0 \\
\hline QF 3 & 29 & 32.8 & 3.8 & & No & & No & & 0.4 & & 0 \\
\hline QF 4 & 34.3 & 37.9 & 3.6 & & No & & No & & 0.5 & & 0 \\
\hline QF 5 & 33.6 & 36.4 & 2.8 & & No & & No & & 0.4 & & 0 \\
\hline QM 1 & 43 & 46.4 & 3.4 & & No & & No & & 0.5 & & 0 \\
\hline QM 2 & 36 & 41.2 & 5.2 & & No & & No & & 0.4 & & 0 \\
\hline QM 3 & 40.1 & 43.3 & 3.2 & & No & & No & & 0.4 & & 0 \\
\hline QM 4 & 37 & 39.9 & 2.9 & & No & & No & & 0.6 & & 0 \\
\hline QM 5 & 35 & 39.6 & 4.6 & & No & & No & & 0.5 & & 0 \\
\hline AF 1 & 24.8 & 30.5 & 5.7 & & No & & No & & 0.3 & & 0 \\
\hline AF 2 & 30.6 & 32.1 & 1.5 & & No & & No & & 0.5 & & 0 \\
\hline AF 3 & 31 & 33.7 & 2.7 & & No & & Yes & & 0.5 & & 0 \\
\hline $\mathrm{AF} 4$ & 26.6 & 28 & 1.4 & & No & & No & & 0.5 & & 0 \\
\hline AF 5 & 28.2 & 30.3 & 2.1 & & No & & No & & 0.2 & & 0 \\
\hline AM 1 & 36 & 38.6 & 2.6 & & Yes & & Yes & & 0.4 & & 3 \\
\hline AM 2 & 37.4 & 41.1 & 3.7 & & No & & Yes & & 0.5 & & 5 \\
\hline AM 3 & 35.3 & 35.5 & 0.2 & & Yes & & Yes & & 0.4 & & 5 \\
\hline AM 4 & 35.6 & 37.4 & 1.8 & & No & & Yes & & 0.4 & & 6 \\
\hline AM 5 & 36.1 & 37.9 & 1.8 & 0.1668 & Yes & 0.0603 & No & 0.0098 & 0.4 & 0.2098 & 0 \\
\hline GFF 1 & 29.5 & 31.4 & 1.9 & & No & & No & & 0.3 & & 0 \\
\hline GFF 2 & 28.5 & 30.4 & 1.9 & & No & & No & & 0.3 & & 0 \\
\hline GFF 3 & 28.4 & 30 & 1.6 & & No & & No & & 0.2 & & 0 \\
\hline GFF 4 & 26.3 & 27.8 & 1.5 & & No & & No & & 0.3 & & 0 \\
\hline GFF 5 & 30 & 31.8 & 1.8 & & No & & No & & 0.4 & & 0 \\
\hline GFM 1 & 35.1 & 36.1 & 1 & & No & & No & & 0.3 & & 0 \\
\hline GFM 2 & 36.1 & 37.1 & 1 & & No & & No & & 0.4 & & 0 \\
\hline GFM 3 & 34.6 & 36.5 & 1.9 & & No & & No & & 0.4 & & 0 \\
\hline GFM 4 & 33.6 & 36.7 & 3.1 & & No & & No & & 0.4 & & 0 \\
\hline GFM 5 & 33.8 & 36.9 & 3.1 & 0.0076 & No & & No & 1 & 0.3 & 0.0005 & 0 \\
\hline CF 1 & 30.5 & 34.1 & 3.6 & & No & & No & & 0.2 & & 0 \\
\hline $\mathrm{CF} 2$ & 27.5 & 28.9 & 1.4 & & No & & No & & 0.3 & & 0 \\
\hline CF 3 & 28.7 & 31 & 2.3 & & No & & No & & 0.3 & & 0 \\
\hline $\mathrm{CF} 4$ & 27.3 & 29.8 & 2.5 & & No & & Yes & & 0.2 & & 3 \\
\hline CF 5 & 29.1 & 30.1 & 1 & & No & & Yes & & 0.3 & & 2 \\
\hline CM 1 & 36.2 & 37.8 & 1.6 & & No & & Yes & & 0.3 & & 4 \\
\hline CM 2 & 37.5 & 38.8 & 1.3 & & No & & Yes & & 0.3 & & 4 \\
\hline CM 3 & 34.8 & 36.6 & 1.8 & & No & & No & & 0.4 & & 0 \\
\hline CM 4 & 34.6 & 36.8 & 2.2 & & No & & Yes & & 0.5 & & 3 \\
\hline CM 5 & 32.1 & 33.3 & 1.2 & 0.0091 & No & & Yes & 0.0034 & 0.3 & 0.0005 & 3 \\
\hline SF 1 & 27.5 & 29.3 & 1.8 & & No & & Yes & & 0.3 & & 2 \\
\hline SF 2 & 28.3 & 30.9 & 2.6 & & No & & Yes & & 0.2 & & 3 \\
\hline SF 3 & 28.9 & 31.1 & 2.2 & & No & & Yes & & 0.2 & & 2 \\
\hline SF 4 & 28.3 & 31.2 & 2.9 & & No & & Yes & & 0.3 & & 3 \\
\hline SF 5 & 27.5 & 29.3 & 1.8 & & No & & Yes & & 0.3 & & 2 \\
\hline SM 1 & 30.2 & 33.2 & 3 & & No & & Yes & & 0.4 & & 3 \\
\hline SM 2 & 34.8 & 37.4 & 2.6 & & No & & Yes & & 0.4 & & 2 \\
\hline
\end{tabular}


Table 2 continued

\begin{tabular}{|c|c|c|c|c|c|c|c|c|c|c|c|}
\hline \multirow[t]{2}{*}{ Animal } & \multicolumn{2}{|c|}{ Weight (g) } & \multirow[t]{2}{*}{ Difference } & \multirow[t]{2}{*}{$p$} & \multirow[t]{2}{*}{ External alteration } & \multirow[t]{2}{*}{$p$} & \multirow[t]{2}{*}{ Internal alteration } & \multirow[t]{2}{*}{$p$} & \multirow[t]{2}{*}{ Lung weight } & \multirow[t]{2}{*}{$p$} & \multirow[t]{2}{*}{ Petechiae } \\
\hline & Initial & Final & & & & & & & & & \\
\hline SM 3 & 36.1 & 38.4 & 2.3 & & No & & Yes & & 0.3 & & 3 \\
\hline SM 4 & 33.6 & 35.8 & 2.2 & & No & & Yes & & 0.4 & & 3 \\
\hline SM 5 & 34.1 & 35.6 & 1.5 & 0.0366 & No & & Yes & 0 & 0.4 & 0.0005 & 1 \\
\hline CFF 1 & 28.5 & 31.2 & 2.7 & & No & & No & & 0.3 & & 0 \\
\hline CFF 2 & 30.4 & 32.3 & 1.9 & & No & & Yes & & 0.3 & & 0 \\
\hline CFF 3 & 28.7 & 30.4 & 1.7 & & No & & No & & 0.4 & & 0 \\
\hline CFF 4 & 26.3 & 27.6 & 1.3 & & No & & No & & 0.2 & & 0 \\
\hline FCF 5 & 27.5 & 30.3 & 2.8 & & No & & No & & 0.3 & & 0 \\
\hline CFM 1 & 34.9 & 37.2 & 2.3 & & Yes & & No & & 0.4 & & 0 \\
\hline CFM 2 & 37.5 & 39.1 & 1.6 & & No & & No & & 0.4 & & 0 \\
\hline CFM 3 & 35.3 & 37.8 & 2.5 & & No & & No & & 0.3 & & 0 \\
\hline FCM 4 & 35.9 & 37.5 & 1.6 & & No & & No & & 0.4 & & 0 \\
\hline CFM 5 & 37.1 & 39.8 & 2.7 & 0.0165 & No & & Yes & 0.1360 & 0.3 & 0.0005 & 0 \\
\hline
\end{tabular}

$Q$ control, $M$ male, $F$ female, $A$ amphibole, $C$ chrysotile, $S$ sepiolite, $C F$ ceramic fibre

sepiolite of sedimentary origin from Spain. The results were always negative and showed the low intrinsic biological activity of this mineral and no exposure-related diseases. However, other sepiolites of non-sedimentary origin (with greater crystallinity and longer fibres), such as those from China and Finland, showed high intrinsic biological activity in animals (Galán 1996). Preliminary studies performed in the present work using sepiolite from Argentina yielded negative results, in agreement with Santarén and Álvarez (1994).

Considering the short exposure times and discontinuous inhalation, the results were positive and showed internal alterations mainly in mice exposed to actinolite-tremolite and chrysotile. These two minerals were collected from Argentine mines that were exploited for decades, so that the people who worked in them may have been exposed to this type of risk.

For data analysis, the groups were divided into quartiles and evaluated. In Table 2 the numbers in italic correspond to values lower than the average; and the ones in bold, to values higher than the average. The remainder corresponds to intermediate values. In addition, a Student's $t$ test was performed for statistical analysis. Table 2 also shows that lung weights and the animals' weight gain were significantly lower in the glass fibre, chrysotile, sepiolite and ceramic fibre groups as compared to the control group, but the lung weights of mice in the amphibole group showed no significant differences in weight with respect to the control group.

The in vitro study of organs did not reveal significant alterations, except for the lungs. The animals in the amphibole, chrysotile and sepiolite groups showed macroscopic alterations with characteristics similar to those of petechiae, which were not observed in the rest of the mineral groups or in the control group.

\section{Conclusions}

1. Some of the natural materials used in the experiments caused pathological alterations. They were collected from Argentine mines that were exploited for decades, with some of them being currently in operation. Therefore, mine workers have been exposed to this type of risk.

2. During the experiment, it was observed that because of the greater volatility of amphiboles, glass and ceramic fibres, experimental animals were more agitated and upset.

3. The autopsy of the animals exposed by inhalation to amphiboles, especially males, showed more externally visible alterations: petechiae, excoriations and decreased subcutaneous fat. These pathological characteristics were not observed in the rest of the animals.

4. The histopathological studies of respiratory system tissues revealed that amphiboles produced greater alveolar wall thickening due to the increase in connective tissue. Chrysotile also caused alveolar wall thickening but to a lesser extent than amphiboles.

5. The results from control animals were compared to those of the animals exposed to the different materials by using Masson's trichrome staining method and TRS. The group exposed to tremolite had TRS 4.7 and the animals exposed to chrysotile, TRS 2. The rest of 
the groups (sepiolite, glass and ceramic fibres) showed no significant differences in the amount of connective tissue with respect to the control group.

6. The statistical analysis confirmed that the control animals gained more weight than the others. There are significant differences between the control group's weight gain and that of the animals treated with asbestiform materials and substitutes; yet, no differences among the groups themselves were found.

7. In relation to the morphology of the materials used in this study, both asbestiform amphiboles and amphiboles of prismatic habit caused injuries to the animals. Although chrysotile and sepiolite exhibit asbestiform characteristics, they caused much less damage due to their greater fibre flexibility and because they agglutinate easily.

8. Substitute materials (glass and ceramic fibres) did not cause lung damage to the animals.

9. The results obtained were positive in view of the shortterm exposure. It would be advisable to perform longer tests in order to confirm the behaviour of these materials due to their long latency period.

Acknowledgments The authors thank Ricardo Camina from the Department of Mathematic, the Departments of Geology and Biochemical Biology and Pharmacy of the Universidad Nacional del Sur, the Comisión de Investigaciones Científicas de la Provincia de Buenos Aires and CONICET. This work was funded by a FONCyT project.

\section{References}

Albin M, Pooley FD, Strömberg U, Attewell R, Mitha R, Johansson L, Welinder H (1994) Retention patterns of asbestos fibres in lung tissue among asbestos cement workers. Occup Environ Med 51(3):205-211

Bernstein DM, Rogers R, Smith P (2005) The biopersistence of Canadian chrysotile asbestos following inhalation: final results through 1 year after cessation of exposure. Inhal Toxicol 17(1):1-14

Bernstein D, Dunnigan J, Hesterberg T, Brown R, Legaspi Velasco JA, Barrera R, Hoskins J, Gibbs A (2013) Health risk of chrysotile revisited. Crit Rev Toxicol 43(2):154-183

Camelo A, Dunmore R, Sleeman MA, Clarke DL (2014) The epithelium in idiopathic pulmonary fibrosis: breaking the barrier. Front Pharmacol. doi:10.3389/fphar.2013.00173

Casado A (1999) Cancer and asbestos. Vaccarezza Institute. University of Buenos Aires. Presented at the I Seminario de Actualización del Asbesto, Trabajo y Salud. Health Ministry, Argentina (In Spanish)

Davis JMG, Addison J, McIntosh C, Miller BG, Niven K (1991) Variations in the carcinogenicity of tremolite dust samples of differing morphology. Third wave of asbestos disease: exposure to asbestos. In: Landrigan PJ, Kazemi H (eds) Annals of the New York Academy of Sciences, vol 643, pp 473-490

Dodson RF, Atkinson MA, O'sullivan M (2005) Stability of ferruginous bodies in human lung tissue following death, embalmment, and burial. Inhal Toxicol 17(14):789-795
Duncan KE, Cook PM, Gavett ST, Dailey LA, Mahoney RK, Ghio AJ, Roggli VL, Devlin RB (2014) In vitro determinants of asbestos fiber toxicity: effect on the relative toxicity of Libby amphibole in primary human airway epithelial cells. Particle Fibre Toxicol 11:2

Galán E (1996) Properties and applications of palygorskite-sepiolite clays. Clay Miner 31:443-453

Goodwin A (1974) Proceedings of the symposium on talc, Washington. Bureau of Mines Information Circular, vol 8639

Guide for the Care and Use of Laboratory Animals (1996) Institute of Laboratory Animal Resources Commission on Life Sciences National Research Council. National Academy Press, Washington

International Centre for diffraction Data (ICDD) (1993) Mineral powder diffraction file. Databook, Park Lane. Swarthmore, Pennsylvania

Jones BF, Galán E (1988) Sepiolite and palygorskite. Hydrous phyllosilicates (Exclu-sive of Micas). In: Bailey SW (ed) Reviews in Mineralogy, Mineralogical Society of America, vol 19, Washington, DC, pp 632-674

Kang D, Myung MS, Kim YK, Kim JE (2013) Systematic review of the effects of asbestos exposure on the risk of cancer between children and adults. Ann Occup Environ Med 25:10

Leake BE, Woolley AR, Arps CE, Birch WD, Gilbert MC, Grice JD, Hawthorne FC, Kato A, Kisch HJ, Krivovichev VG, Linthout K, Laird J, Mandarino JA, Maresch WV, Nickel EH, Rock NMS, Schuhmacher JC, Smith DC, Stephenson N, Ungaretti L, Whittaker E, Youzhi G (1997) Nomenclature of amphiboles: report of the subcommittee on amphiboles of the International Mineralogical Association, commission on new minerals and mineral names. Can Mineral 35:219-246

Marín Martínez B, Clavera I (2005) Asbestosis. An Sist Sanit Navar 28(Supl. 1):37-44

Matos EL, Loria DI, Zengarini N (1997) Atlas of cancer mortality in Argentina between 1989 and 1992. Edición del Comité Argentino de Coordinación Programa Latino América Contra el Cáncer. Buenos Aires, Argentina, pp 10-30 (In Spanish)

Murray HM (1907) Report of the Departmental committee on compensation for industrial diseases. Minutes of evidence. CD 3946 Her Majesty's Stationery Office, London, pp 127-128

Nishimura Y, Maeda M, Kumagai-Takei N, Lee S, Matsuzaki H, Wada Y, Nishiike-Wada T, Iguchi H, Otsuki T (2013) Altered functions of alveolar macrophages and NK cells involved in asbestos-related diseases. Environ Health Prev Med 18:198-204

OECD (2009) Guidance document on acute inhalation toxicity testing. Environmental health and safety monograph series on testing and assessment, vol 39. OECD, Paris. http://www.oecd. org/env/testguidelines

Pérez JE, Oresti GM, Melatini G, Bertón P, Ullua N, Gandini NA, Gigola G, Zwenger AO, Fermento ME (2006) Clinical histories and daily reports for research: tools for carcinogenesis studies in animal models. Oncología Clínica 11(1):1278-1284 (In Spanish)

Robinson BM (2012) Malignant pleural mesothelioma: an epidemiological perspective. Ann Cardiothorac Surg 1(4):491-496

Rodríguez EJ (2004) Asbestos banned in Argentina. Int J Occup Environ Health 10:202-208

Roggli VL, Vollmer RT (2008) Twenty-five years of fiber analysis: what have we learned. Hum Pathol 39:307-315

Ross M, Nolan RR, Langer AM, Cooper WC (1993) Health effects of mineral dusts other than asbestos. In: Guthrie GD, Mossman BT (eds) Health effects of mineral dusts, reviews in mineralogy, vol 28. Mineralogical Society of America, Washington, D.C., pp 361-407

Rowlands N, Gibbs GW, McDonald AD (1982) Asbestos fibres in the lungs of chrysotile miners and millers-a preliminary report. Ann Occup Hyg 26:411-415 
Sánchez VC, Pietruska JR, Miselis NR, Hurt RH, Kane AB (2009) Biopersistence and potential adverse health impacts of fibrous nanomaterials: what have we learned from asbestos? Wiley Interdiscip Rev Nanomed Nanobiotechnol 1:511-529

Santarén J, Álvarez A (1994) Assessment of the health effects of mineral dusts. The sepiolite case. Ind Miner 1-12

Skinner HCW, Ross M, Frondel C (1988) Asbestos and other fibrous materials. Oxford University Press, UK

Valeyre D, Letourneaux M (1999) Asbestose. Rev Mal Respir 16:1294-1307
Van Oss CJ, Naim JO, Costanzo RM, Giese RE, Wu W Jr, Sorling AE (1999) Impact of different asbestos species and other mineral particles on pulmonary pathogenesis. Clays Clay Miner 47(6):697-707

Wicks FJ, Whittaker EJW (1975) A reappraisal of the structures of the serpentine minerals. Can Miner 13:227-243 